\section{APPOINTMENTS VACANT}

APPLICATIONS are invited for the following appointments on or fore the dates mentioned

ASSISTANT EXPERIMENTAL OFFICRR (male, under 28 on December 31 1958 , with a degree in forestry or botany with subsidiary chemistry and an interest in ecology and scottish woodlands), for work on fores Nature Conservancy (E), 19 Belgrave Square, London, S.W.1 (August 22)

LECTURER (with a degree in botany or in agricultural botany, teaching and/or research experience, and preferably experience in genetics and plant breeding) IN AGRICULTURAL BoTANY in the Department of Agriculture, Kumasi College of Technology-The Council for Overseas Colleges, 12 Lincoln's Inn Fields, London, W.C.2
(August 22). RESEARCH FELLOW or SENIOR RESEARCH FELLOW IN THE DEPARTMENT OF PURe Mathematics-The Registrar, The University, Birmingham 15 (August 22)

SENIOR LECTURER Or LECTURER (with a degree in veterinary medicine, teaching and/or research experience, and preferably ex perience in a tropical country) IN VETERINARY SCIENCE in the Departfor Overseas colleges, 12 Lincoln's Inn Fields, London, W.C.2 (August 22).

SENIOR LECTURER (with a good honours degree and teaching experience) IN APPLIED MATHEMATICS at the Nigerian College of Arts, Science and Technology-The Secretary, Council for O 12 Lincoln's Inn Fields, London, W.C.2 (August 22). appropriate teaching and industrial experience) of THE D PARTMEN College, Crocketts Lane, Smethwick (August 23).

College, Crocketts Lane, Smethwick (August 23).
SENIOR LEcTURER IN RADIOCHEMISTRY at the New South Wales University of Technology, Kensington, New South Wales, AustraliaThe Agent General for New South Wales, 56 Strand, London, W.C.2 (Australia, August 25).

Lecturer in the Department of Mathematical Physics-The Secretary, The University, Edinburgh (August 29).

ASSISTANTS (2) IN ChEMISTRY (one INORGANIC and one PHYSICAL) -The Secretary, The University, Aberdeen (August 30).

A Secretary, The UR (with special qualifications in organic chem istry) IN CHEMISTRY - The Registrar, The University, Manchester 13 (August 31).

BIOMETRICIAN with the Government of the Federation of Rhodesia and Nyasaland, for duties which will include design of experiments in all phases of agriculture and animal husbandry research and analysis of data and related statistical practice-The Secretary $(R)$ Rhodesia House, 429 Strand, London, W.C.2 (September 7)

ASSISTANT IN STATISTIOS-The Secretary, The University, Aberdeen September 12).

LECTURER (preferably with experience and interests in cytogenetics) IN BOTANY at the University College of Rhodesia and NyasalandThe Secretary, Inter-University Council for Higher Educat

seas, 29 Woburn Square, London, W.C.1 (September 12). ASSISTANT LECTURER (with special qualifications in applied mathematics) IN MATHE

13 (September 15). LECRORER or ASSISTANT LECTURER IN GEOLOGY at the University of Malaya-The Secretary, Inter-University Council for Highe 15).

Lecturer or Assistant Lecturer in Pharmacology at the iniversity of Malaya-The Secretary, Inter-University Council for (September 15).

CHAIR OF ChEmistry - The Secretary to the Curators of Patronage, The University, 4 Albyn Place, Edinburgh 2 (September 30).

CHAIR OF LARYNGOLOGY AND OTOLOGY at the Institute of Laryngology and Otology-The Academic Registrar, University of London, Senate House, London, W.C.1 (October 31).

ASSISTANT EXPERIMENTAL OFFICER (with a degree in chemistry o aricultural chemistry or equivalent qualifications), to carry out chemical analyses of soils and plants; and an ASSISTANT EXPERIMENTAL OFFICER Or EXPERIMENTAL OFFICER, for biological work in connexion with the study of strains of insects resistant to insecticide -The Secretary, Rothamsted Experimental Station, Harpenden, Herts. ASSISTANT, Grade B, IN THE ELECTRICAL ENGINEERING AND Physics DaParTMENT, Coventry Technical College, to teach physic in National Certificate, Sandwich and Degree Courses to full-time, part-time day and evening students-Director of Education, Council

ASSISTANT LECTURER AND DEMONSTRATOR IN PhYSIOLOGY-The Secretary, Queen Elizabeth

ASSISTANT WARDEN (male, with a degree in zoology, and an interest in ornithology and marine or freshwater biology, and preferably some research experience) AT FLATFORD MUL FIELD CENTRE; and a FIEID ASSISTANT (female, with a university degree in geography or natural sciences) The Secretary and Treasurer, Fondon, E.C.2.

BIOLOGIST (with postgraduate experience of experimental anima york), for cancer research-Prof. K. R. Hill, Pathology Department, Royal Free Hospital, London, W.C.1.

Royal Free Hospital, London, W.C.T. Institute for Research in Dairying, Shinfleld, Reading, quoting Ref. $58 / 23$.

ORGanic AND Physical Cifemists, for research in the following fields: colloid chemistry of latex and related emulsions, polymerizations in emulsions and solid systems, mechanism of the ozonolysis of organic compounds and its control-The Director of Research, British

Garden City, Herts. research experience, preferably in synthetic work), to join in research on biological action and molecular structure of organic compoundsTedical Research Council, Western Infirmary, Glasgow, W.1 READER IN MECHANICAL ENGINEERING, and a READER IN ELECTRICAL ENGINEERING - The Principal, The Institute of Technology,

RESEARCH ASSISTANTS (with a good honours degree), to carry out fundamental research in $(a)$ problems in organic chemistry and (b) electronics, high vacuum problems or interferometry-The Clerk of Art, Longbridge Road, Dagenham.

TECHNICAL RESEARCH ASSISTANT IN THE PHYSIOLOGY DEPART. MENT-The Secretary, Queen Elizabeth College (University of London). Camp-The Secretary, Queen Elizabeth

TECHNICIAN (with experience in histological and photographic techniques, and preferably also in the general work of an anatomy department) IN THE ANATOMY DEPARTMENT - The Secretary, Guy's Hospital Medical School, London Bridge, London, S.E.1.

\section{REPORTS and other PUBLICATIONS}

(not included in the munthly Books Supplement)

\section{Great Britain and Ireland}

Ministry of Agriculture, Fisheries and Food. Domestic Food Consumption and Expenditure 1956: Annual Report of the National
Food Survey Committee. Pp. iv +172 . (London: H.M. Stationery Office. 1958.) 9s. 6d. net. Pp. iv +172. (London: H.M. Stationery
[77 Bulletin of the British Museum (Natural History). Historical and ol. 1, No. 5: The Gronovius Fish Collection: a Catalogue $26-34 \quad 20 s$. The Culicine Mosquitoes of the Ind $185-249+$ plates Part 3 : Genus Aëdes Meigen, subgenera Paraëdes Edwards, Rhinoskusea Edwards and Cancraedea Edwards. By P. F. Mattingly. Pp. 61. 12s. (London: British Museum (Natural History), 1958.) [77 The Ninth Annual Report of the Wildfowl Trust, 1956-195i. Edited by Peter Scott and Hugh Boyd. Pp. 240 (32 plates). (London:
Country Life, Ltd., 1958. Published for the Wildfowl Trust.) 108. net. Colonial Office. The Colonial Territories 1957-1958. Pp ${ }^{[}[7 \overline{7}$ 171. (Cmnd. 45i.) (London: H.M. Stationery Office, 1958.) 9s. net. cal Report No. 4: Industrial and Economic Microbiology in North America. By A. W. J. Bufton. Pp. iv + 37. (London: H.M. Stationery Office, 1958 .) $2 s$. $6 d$. net. Ministry of Power. Reports of H.M. Inspectors of Mines and
Quarries under the Mines and Quarries Act, 1954, for 1957. NorthumQuarries under the Mines and Quarries Act, H. Hyde. Pp. iv $+41+6$ plates. (London: H.M. Stationery Office, 1958.) 3s. 6d. net.

\section{Other Countries}

United States Department of Agriculture. Leaflet No. 161: The Eastern Tent Caterpillar. By B. A. Porter. Pp. 5. (Washington, D.C.: Government Printing Office, 1958.) l'Etude Agronomique du Congo Belge. Série Scientiflque. No. 71: Helopeltis du Cotonnier en Afrique Centrale. Par G. Schmitz. Pp. 178. 160 Belgian francs. No. 74: Géographie Humaine de la Région de Bengamisa. Par H. Beguin. Pp. 69. 60 Belgian franes. (Bruxelles: Institut National pour l'Étude Agronomique du Congo Belge, 1958.)
Deutscher Wetterdienst. Deutsches Meteorologisches Jahrbuch 1956. Pp. xxxvi +230. (Offenbach (Main): Deutscher Wetterdienst, 1958 .)

Republic of the Sudan. Annual Report of the Government Analyst for the year 1956-57. Pp. 19. (Khartoum: Wellcome Chemical
[77 Carnegie Institute of Washington. Researches of the Department of Terrestrial Magnetism, Vol. 20 (Publication No. 175): Cosmic-Ray Results. Huancayo, Peru, January 1946-December 1955. Cheltertham, Maryland, March 1936-December 1955. Christchurch, New Zealand, January 1947-December 1955. Godhavn, Greenland, January Institution of Washington, 1957.) Paper, 2 dollars; Cloth, 2.25 dollars.

Naval Research Laboratory, Washington, D.C. NRL Report $5087^{7}$ : Upper Atmosphere Research Report No. 32: History of the UpperAir Rocket-Research Program at the Naval Research Laboratory, 1946-1957. By J. W. Townsend, Jr., H. Friedman, and R. Tousey. Pp. ii +47 . (Washington, D.C.: Naval Research Laboratory, 1958.
Distributed by Office of Technical Services.)

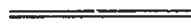

Editorial and Publishing Offices of "NATURE"

MACMILLAN \& CO., LTD.,

ST. MARTIN'S STREET, LONDON, W.C.2.

Telephone Number: Whitehall 8831. Telegrams: Phusis Lesquare London

Annual subscription $£ 7 / 15 /-$, payable in advance, postage paid to any part of the world

Advertisements only should be addressed to

T. G. Scott \& Son, Ltd., I Clement's Inn, London, W.C.2 Telephone Number: Holborn 4743 